\title{
Prelicensure nursing students' perceptions of a rapid transition to an online learning environment
}

\author{
Elizabeth S. Green-Kronebusch, Jacqueline K. Savalle, Victoria G. Mrowka \\ School of Nursing, Winona State University, Minnesota, USA
}

Received: August 4, 2021

Accepted: November 10, 2021

Online Published: November 24, 2021

DOI: $10.5430 /$ jnep.v12n4p12

URL: https://doi.org/10.5430/jnep.v12n4p12

\begin{abstract}
Background/Objective: The need to transition to an online learning environment secondary to the COVID-19 pandemic required prelicensure nursing educators and students to become rapidly familiar with new teaching modalities. There is insufficient evidence to support the effectiveness of, and satisfaction with, the online learning environment in prelicensure nursing education due to historic underutilization of online methods and lack of research. The aim of this study was to evaluate the experiences and satisfaction of prelicensure nursing students with regards to effective teaching modalities following a rapid transition from the traditional to online learning environment.

Methods: This study was a secondary analysis of data from an online survey of 215 students registered for the prelicensure nursing major at a medium sized state university in the American Midwest in the spring semester of 2020. During this semester, a rapid transition from the traditional to online learning environment occurred as a result of the COVID-19 pandemic. Analysis within this secondary study focused on a series of open-ended questions inviting students to comment on the effectiveness of, and satisfaction with, online learning, together with perceived barriers, advantages and disadvantages in the context of a rapid transition to an online learning environment during the spring semester 2020. Framework analysis was utilized for the secondary qualitative data analysis.

Results: Four themes were identified in the secondary analysis of the survey responses from the primary study which appeared to shape the students' experiences of the shift to online learning. These were: learning environment, course design and delivery, communication, and learner characteristics. Analysis of open-ended responses suggested each of these themes could be experienced by students along a continuum ranging from unfavorable to favorable. The combination of each student's experiences along these continua appear to cumulatively impact and predict their success in the online learning environment.

Conclusions: Perceptions of online learning were personal to, and differed between, individual students. Faculty can directly impact two of the themes identified: course design and delivery and communication. Individualization of the student's learning experience through tailored course delivery and support of learning needs will aid in increased satisfaction and successful learning outcomes. Analysis of open-ended responses suggested that each of these themes could be experienced by students along a continuum ranging from unfavorable to favorable. The combination of each student's experiences along these continua appear to cumulatively impact and predict their success in the online learning environment.
\end{abstract}

Key Words: Undergraduate nursing, Online education, COVID-19

\section{INTRODUCTION}

The transition to a fully online environment after the spread of the COVID-19 pandemic left educators with the need to quickly transition didactic classes to the online environment and attempt to understand and utilize online teaching modalities. Online learning has only recently become integrated

*Correspondence: Elizabeth S. Green; Email: elizabeth.green@ winona.edu; Address: School of Nursing, Winona State University, Minnesota, USA. 
within nursing education, creating a gap in literature in relation to the most appropriate strategies for online education, specifically in prelicensure nursing.

\subsection{COVID-19}

At the beginning of 2020, the World Health Organization (WHO) declared COVID-19 a global pandemic. ${ }^{[1]}$ Due to the ease of transmission of the virus, many states enacted stay-athome orders encouraging citizens to leave their homes only for essential tasks such as obtaining groceries and medical needs, in conjunction with facial mask mandates and limitations to group gatherings. The CDC released updated Guidelines for the Institutions of Higher Education strongly encouraging educational institutes to follow local public health departmental recommendations in order to slow the spread of the virus and ensure the health and safety of students, staff, and faculty. ${ }^{[1]}$ This led to most universities transitioning to fully online programs midway through the spring semester of 2020.

\subsection{Online learning in higher education}

The use of the internet and advancements in technology have expanded student learning capabilities exponentially over time. ${ }^{[2]}$ The current generation pursuing higher education is computer literate making the online learning environment an effective way of reaching students. This requires different instructional methods than a traditional classroom. ${ }^{[2]} \mathrm{Re}-$ search showed combining online and face-to-face instruction, known as blended learning, results in higher achievement, higher student satisfaction, stronger student persistence comment and increased flexibility in teaching and learning. ${ }^{[3]}$ It is important to address the effectiveness of, and satisfaction with these new delivery methods. The student perspective of this transition was critical to consider. With the everchanging fields of nursing, healthcare, and education, it is the educator's responsibility to create a successful educational environment to support learners.

\subsection{Learning environments}

Three main methods of educational delivery are utilized in higher education including the traditional learning environment, online learning environment, and hybrid learning environments.

Traditional learning environments involve students being physically present in a classroom with a professor(s), didactic instruction, structured class time, lectures, writing activities, and exams occurring with the instructor and students together in-person. ${ }^{[4]}$ Historically, the traditional learning environment in nursing education consisted of face-to-face lectures in a physical classroom, skills practice or simulation in a lab, and clinical experiences within the hospital and community settings. These methods are often utilized in conjunction with an online platform for ease of access to classroom resources and enhanced communication between students and faculty.

Online learning environments (also referred to as virtual or e-learning) utilize a digital platform for all instruction and evaluation while connected to the internet and can be synchronous or asynchronous. ${ }^{[4]}$ "Online learning uses the internet paired with various types of software such as learning management systems, learning portals, e-learning platforms, virtual learners' environment, or course management system." [4] The online learning environment encompasses many methods and tools such as videos, podcasts, and interactive websites which can aid in students' retention of knowledge and application to practice. ${ }^{[4]}$ Online learning has been associated with an increased workload for educators due to these various tools which require an increased need for preparation by instructors when compared to face-to-face instruction. ${ }^{[4]}$ Faculty teamwork and student engagement greatly factor into the success of online delivery. ${ }^{[5]}$

The United States Department of Education ${ }^{[6]}$ refers to hybrid or blended learning as a combination of online learning with face-to-face instruction. A combination of online learning and technology will be necessary to adequately prepare future nurses due to the increased integration of technology in the healthcare field. ${ }^{[4]}$

\section{REVIEW OF LITERATURE}

To explore the phenomenon of prelicensure undergraduate nursing students' experience and perception of online learning following rapid transition from a traditional learning environment, a review of literature was completed. While investigating this topic, very little research was found regarding the transition to online learning for prelicensure nursing students. This shifted the focus of the literature review to better understand what prelicensure nursing students perceive as effective and satisfying in online learning environments and teaching methods.

\subsection{Search strategy}

The literature search utilized databases including CINAHL, PubMed, and ERIC. Search terms were established through combining population (undergraduate or prelicensure nursing students) with subject (traditional learning, online learning, and/or hybrid learning), and outcome (satisfaction and effectiveness with education). These searches were further limited to academic articles published in the last ten years and articles written in the English language. Upon critical analysis of the literature, themes emerged in relation to outcomes for evaluating prelicensure nursing education, including motiva- 
tion and attitude, self-efficacy, learning effectiveness, skill acquisition, and learner satisfaction.

\subsection{Motivation and attitude}

Many articles provided information on student motivation and attitudes toward traditional, online, and hybrid learning. Some studies measured students' motivation while evaluating the effectiveness of online learning versus hybrid or traditional learning in prelicensure nursing students. ${ }^{[7,8]}$

Li et al. ${ }^{[9]}$ performed an analysis on eight studies examining how blended learning affects nursing students' knowledge, skills, and satisfaction. They found nursing students expressed a positive outlook with the online learning environment, however, reported that online delivery as a sole method of instruction was not their first choice. ${ }^{[9]}$ Gagnon et al. ${ }^{[7]}$ commented that teaching delivery does not affect motivation, rather the personal teaching style of each instructor aids in student motivation. Overall, evidence from articles reviewed was conflicting regarding the theme of motivation and attitude across different learning environments.

\subsection{Self-efficacy}

Bastable ${ }^{[10]}$ emphasizes the importance of self-efficacy (belief in oneself), in nursing education and argues that this must be maintained in an online learning environment to achieve learning objectives. Multiple studies reviewed utilized selfefficacy as an outcome measure, though there was variation in how this was measured.

Two studies examined self-efficacy within online learning environments by evaluating pre and post-test scores compared to traditional and blended learning approaches. ${ }^{[11,12]}$ In the systematic review conducted by Cant and Cooper ${ }^{[11]}$ two articles addressed self-efficacy, finding significant improvements in self efficacy within the online learning environment in one. Shorey et al. ${ }^{[12]}$ also found increased scores on the communication self-efficacy scale when implementing a blended learning intervention. Conversely, Chan et al. ${ }^{[13]}$ found no difference in self-efficacy between face-to-face and web-based approaches in case-based learning. Again, evidence from the studies reviewed was conflicting.

\subsection{Learning effectiveness}

Perception of learning effectiveness on the part of prelicensure nursing students was identified as a common theme within reported outcomes in the majority of studies reviewed. There was variation in how this outcome was both measured and reported across the studies. Measurements included posttest scores, exam scores, subjective assessment of student comprehension of knowledge following a simulation-based intervention, and student questionnaire responses.
In research by Giddens et al., ${ }^{[14]} 695$ undergraduate nursing students in a university within the U.S. were surveyed after use of a virtual community with patient scenarios. It was found the use of this virtual community aided students in understanding patient conditions. Gill et al. ${ }^{[15]}$ in a systematic review of 20 articles evaluating pharmacology teaching methodologies in undergraduate nursing students found online methods, simulation, and integration of content within other nursing curricula were most effective in acquisition of knowledge. Two studies indicated a favorable outcome for blended learning when compared to either the traditional learning environment alone, or the online learning environment alone. ${ }^{[8,9]}$ In two studies ${ }^{[7,16]}$ comparing online or blended versus face to face, mixed results were noted but most papers reviewed reported on a similar or higher level of knowledge following an online teaching intervention. In the transition from traditional to blended or online learning environments, two studies reported no significant differences in post-test scores and learning effectiveness respectively. ${ }^{[17,18]}$

Overall evidence from articles reviewed was conflicting regarding the theme of learning effectiveness. In the studies reviewed, evidence for positive, negative, and mixed results of learning effectiveness were reported.

\subsection{Skill acquisition}

Skills driven classes focus on nursing skills and the student's ability to adequately perform them. William et al. ${ }^{[19]}$ reviewed the difference between virtual reality simulation and traditional classroom method of phlebotomy education in 62 undergraduate nursing students in Kuwait. They found no significant difference between the groups, suggesting that this education is effective with both methods. Three studies in a review of literature by $\mathrm{Li}$ et al. ${ }^{[9]}$ reviewed skill acquisition; these results were combined and analyzed by their team. They found a trend towards skill improvement in the hybrid course over traditional learning, but this was not statistically significant. ${ }^{[9]}$ In a systematic review by McCutcheon et al., ${ }^{[16]}$ thirteen of the nineteen studies reported on clinical skills following online education. Minimal statistical data were reported; however, they describe six studies which found significantly positive results following online education intervention. Three studies had inconclusive results, and six studies demonstrated no statistically significant differences. ${ }^{[16]}$

\subsection{Learner satisfaction}

Several studies found high levels of satisfaction with an online learning environment. ${ }^{[5,20,21]}$ In a qualitative study, Esposito and Sullivan ${ }^{[5]}$ found students reported feeling overwhelmingly satisfied with virtual simulation during the 
COVID-19 pandemic and found importance in group work while faculty promoted engagement.

In a systematic review evaluating online or blended learning versus face-to-face learning of clinical skills in undergraduate nursing education by McCutcheon et al., ${ }^{[16]} 11$ of 19 articles reported on the outcome of satisfaction with varied results. Three other studies found similar results indicating that there is no difference in satisfaction between traditional and online learning environments. ${ }^{[7,13,18]}$ Students felt more successful in their education with the addition of technology support, audio visual aids, discussion forums with classmates, and affirmational support from peers. ${ }^{[9,22]}$ Learner satisfaction was a complex outcome, utilizing various measurements in the studies reviewed. Additionally, reported outcomes were mixed in the satisfaction expressed by learners. Therefore, no one learning environment was associated with a higher level of learner satisfaction over another.

\section{Methods}

This study was a secondary analysis of data from a primary study, with a purpose to examine how the learning experiences of undergraduate nursing students were affected as a result of the COVID-19 pandemic and resulting rapid transition to online learning. The primary study consisted of an online survey of 215 students registered for the prelicensure nursing major at a medium sized state university on two campuses in the American Midwest. The response rate of the students who completed the survey was $72 \%(215 / 300)$. Refer to Table 1 for demographic data for participants of campus A and campus B.

Table 1. Demographic data for study participants

\begin{tabular}{ll}
\hline Campus A & Campus B \\
\hline $93 \%$ White & $93 \%$ White \\
$2 \%$ Asian & $3 \%$ Asian \\
$1 \%$ Hispanic & $1 \%$ Hispanic \\
$1 \%$ American Indian & $3 \%$ two or more \\
$1 \%$ Black & \\
$2 \%$ two or more & \\
$1 \%$ unknown & \\
$94 \%$ female & $93 \%$ female \\
$6 \%$ male & $7 \%$ male \\
\hline
\end{tabular}

The survey instrument used in the primary study included a combination of structured and open-ended questions exploring different aspects of the online learning environment. Data were collected on the effectiveness of, and satisfaction with, online learning, together with perceived barriers, advantages and disadvantages in the context of a rapid transition to an online learning environment during the spring semester of 2020 .
In addition to reporting demographic data, the secondary analysis focused upon qualitative data generated in response to a number of open-ended questions. The researchers utilized a modified framework analysis, ${ }^{[23]}$ which consisted of five stages: familiarization, coding, plotting data onto identified codes, identifying emerging themes, synthesizing themes into main concepts, and reviewing data to ensure transparency and rigor of the analysis. ${ }^{[24]}$ Familiarization with the data involved three researchers independently reading through the descriptive data in order to gain a sense of breadth and variability of the responses. The researchers then coded the responses and entered identified codes onto an excel spreadsheet, initially creating one sheet for each of the research questions. An overlap in responses was noted by the researchers. Next, they utilized the initial codes to map student responses onto the codes. The researchers collaborated and identified emerging themes and subthemes across the sheets for each research question. Following discussion, the researchers then condensed the codes into seven mutually agreed upon themes which could be observed over a continuum. Researchers further synthesized these into four overarching themes of learning environment, course design and delivery, communication, and learner characteristics. These themes, and relevant sub-themes are described, together with illustrative quotes from student responses.

\section{RESULTS}

This study aimed to evaluate the experiences of prelicensure nursing students with regards to effective teaching modalities and satisfaction following a rapid transition from the traditional to online learning environment due to the COVID-19 pandemic.

The study aimed to answer the following questions:

1) What are students' perceptions of advantages and disadvantages of online learning?

2) Which aspects of online learning are students most satisfied with?

3) Which aspects of online learning are students most dissatisfied with?

4) What barriers to online learning do students identify?

After analyzing the data, four main themes emerged that appeared to influence students' experiences of the move to online learning. These were: learning environment, course design and delivery, communication, and learner characteristics. A main finding was the perception of online learning in relation to advantages, disadvantages, satisfiers, dissatisfiers and barriers were personal to, and differed between, individual students. Table 2 provides select students' responses to illustrate the main themes and sub-themes. 
Table 2. Selected student responses categorized by themes

\begin{tabular}{|c|c|c|}
\hline Main theme & Sub-theme & Illustrative quotes \\
\hline \multirow[t]{2}{*}{$\begin{array}{l}\text { Learning } \\
\text { Environment }\end{array}$} & Home environment & $\begin{array}{l}\text { "I could switch up my learning environment whether it was a different room in my house or outside on the patio." } \\
\text { "I enjoy seeing my family but miss the face-to-face interaction. I feel like I can get more done and have gotten } \\
\text { better sleep as well being at home." } \\
\text { "For me personally, [I] just felt like I had a difficult time keeping on top of things especially when my whole } \\
\text { family is in the house and there's multiple distractions at place[sic]." } \\
\text { "My place of relaxation has been forced into becoming an academic environment so now I have nowhere to relax. } \\
\text { There is no place available to take quizzes or tests in peace. The noise of roommates carrying out their daily lives } \\
\text { in between classes is highly distracting and detrimental to my grades." }\end{array}$ \\
\hline & Internet & "My internet connection is often very spotty because of all of my family doing online schooling and working.” \\
\hline \multirow{5}{*}{$\begin{array}{l}\text { Course Design } \\
\text { and Delivery }\end{array}$} & $\begin{array}{l}\text { Self-pace/Flexibilit } \\
\text { y/Structure }\end{array}$ & $\begin{array}{l}\text { "I really like recorded lectures rather than having a PowerPoint to just read over yourself. I know synchronous is } \\
\text { more challenging as students are working throughout the day but having these classes and having to be on zoom } \\
\text { allows for a normal schedule and ability to ask questions.” } \\
\text { "Prerecorded lectures don't allow students to make questions in real time.” } \\
\text { "I feel like it was difficult to keep track of new assignments and manage everything. I also felt like some classes } \\
\text { added even more time-consuming tedious tasks to make up for being online." }\end{array}$ \\
\hline & $\begin{array}{l}\text { Lecture Breaks and } \\
\text { Engagement }\end{array}$ & $\begin{array}{l}\text { “...[O]ffer brief periods of rest from lecturing to give a break from staring at a computer screen.” } \\
\text { "I would recommend more interactive tools such as class polls, Kahoot’s, videos, games etc. Looking at a screen } \\
\text { for days can make people sleepy, so asking questions and involving the audience helps!” }\end{array}$ \\
\hline & $\begin{array}{l}\text { Content and } \\
\text { Assignments }\end{array}$ & $\begin{array}{l}\text { "Some classes allowed open notes on the quizzes and increased time to take exams." } \\
\text { "Learning in this format was so difficult. A lot of professors had to cut down course content. Likewise, I feel like } \\
\text { the exams being open book were not beneficial because I feel like I was not forced to study and know the } \\
\text { information as well." }\end{array}$ \\
\hline & Virtual Simulation & $\begin{array}{l}\text { "I thought the Vsims did a fantastic job of targeting very specific diagnosis or complications and provided a very } \\
\text { good learning experience with in-person experiences not possible..." } \\
\text { "Simulations not as rigorous as in person (clinical, skills lab)" }\end{array}$ \\
\hline & Group Work & $\begin{array}{l}\text { "I would continue to do more group work sessions or mini projects that keep us involved with other students and } \\
\text { allow us to share ideas while we are isolated. Presentations and group projects were easier to accomplish remotely } \\
\text { than I anticipated..." } \\
\text { "The group work was more difficult than usual." } \\
\text { "I would feel better still being able to do the work 'in class' together as to make sure I fully understand it and am } \\
\text { able to complete it. Allow for peer revisions or continuing to be in groups for some activities." }\end{array}$ \\
\hline \multirow{4}{*}{ Communication } & $\begin{array}{l}\text { Between Students } \\
\text { and Faculty }\end{array}$ & $\begin{array}{l}\text { "Since moving to an online format, this is the most accessible my professors have ever been. It has been incredibly } \\
\text { helpful to be able to quickly get in touch with them regarding questions." } \\
\text { "In class we are able to have actual interactions with professors and ask questions about lectures (during an actual } \\
\text { lesson) and can also learn from other students' questions about that material." } \\
\text { "Communication is KEY. The professors should provide a good, solid outline of assignments so that we know } \\
\text { what is due when and when dates are being changed." }\end{array}$ \\
\hline & Virtual Meetings & $\begin{array}{l}\text { "I have found (the) meetings schedule with the faculty has been very helpful during this time. It gives me some } \\
\text { structured times and I am able to get my questions answered. I feel that if these were more frequent, the online } \\
\text { setting could be improved." }\end{array}$ \\
\hline & $\begin{array}{l}\text { Learning } \\
\text { Management } \\
\text { System (LMS) }\end{array}$ & $\begin{array}{l}\text { "Not having the in-person clarification for assignments. Having to understand what was happening through } \\
\text { [school specific LMS] which was highly confusing towards the end of the semester with all of these [group } \\
\text { evaluations]. I was kind of lost with all the things in the assessments page - honestly confusing." }\end{array}$ \\
\hline & Classmates & $\begin{array}{l}\text { "The shy kids got a chance to be more interactive on zoom using the chat." } \\
\text { "Learning how to use Zoom was probably more beneficial for writing our group papers than having to meet } \\
\text { somewhere else and do it. Zoom has made meeting for classes more efficient.” } \\
\text { "Reduce group work as much as possible. It's difficult to carry out the same level of work needed to succeed on } \\
\text { assignments when working over online formats." }\end{array}$ \\
\hline \multirow{4}{*}{$\begin{array}{l}\text { Learner } \\
\text { Characteristics }\end{array}$} & $\begin{array}{l}\text { Time } \\
\text { Management }\end{array}$ & $\begin{array}{l}\text { "I can do things on my own time and have smaller lengths of worktime compared to having to sit through long } \\
\text { periods of class at once where I lose focus more often. I can spend more time learning to understand things that } \\
\text { might not come as easily to me compared to being in class and going with the pace of the professor." }\end{array}$ \\
\hline & $\begin{array}{l}\text { Motivation and } \\
\text { Attention }\end{array}$ & $\begin{array}{l}\text { "I struggle to maintain level of motivation needed for nursing school and often felt overwhelmed with } \\
\text { PowerPoints, emails, and all the different class schedules" } \\
\text { "It's hard to stay motivated to finish the day when you're online." }\end{array}$ \\
\hline & $\begin{array}{l}\text { Work, School, Life } \\
\text { Balance }\end{array}$ & $\begin{array}{l}\text { "It allowed for more flexibility, in that I could work or take time for myself and still be able to do the work on } \\
\text { time." }\end{array}$ \\
\hline & Self-Teaching & $\begin{array}{l}\text { "The recorded lectures were very helpful for going back over things that were discussed in class" } \\
\text { "Having more concrete schedules for the online course would be helpful to keep things straight when we cannot } \\
\text { see our professor or ask questions with readily available answers. One of my courses had no supplemental class } \\
\text { time on zoom and this hindered my learning for the class, so I recommend more zoom class time for online } \\
\text { courses.” } \\
\text { "It's hard to learn when you can't ask questions when you think of them or see someone do a skill. And you can't } \\
\text { practice your skills because we don't have the equipment like we do in lab.” }\end{array}$ \\
\hline
\end{tabular}




\subsection{Learning environment}

Students frequently described advantages, disadvantages and barriers to online learning in relation to the environment in which online instruction occurred. Some found their home environment advantageous to their learning experiences due to benefits such as enhanced comfort and improved sleep hygiene, while others reported their environment as a barrier to their online learning due to disruptions to routine, presence of family members, poor internet connections, and technical issues.

\subsection{Course design and delivery}

Students described varying preferences in relation to course design and delivery, including content delivery, assignments and exams, and clinical replacement. Some students appreciated the flexibility of asynchronous classes whilst others enjoyed the structure of synchronous course delivery. Disadvantages included disorganization of the learning management system (LMS), undefined expectations, and difficulties with motivation. Students offered a wealth of suggestions for future content delivery including lecture breaks, use of more engaging teaching methods, and increased structure through release of course content within the LMS weekly. Assignments and exams were reported by some students as being overwhelming in the online learning environment and commented how student expectations, given the historical context of class delivery, were not met. However, others appreciated the less formal approach to testing in some online classes. Students' reactions to replacement activities for clinical experiences, such as simulations, were also varied, with some identifying these as a barrier to meeting their learning objectives, while others seemed satisfied. One primary advantage to content delivery in the online learning environment reported by students was the ability to enhance meaningful group work. Overall, students had varied responses.

\subsection{Communication}

Communication was one of the most evident themes impacting student experiences, echoing findings from the literature review. Survey responses included information on students' experiences and preferences for communication between students and faculty members as well as communication between fellow classmates. Overall disadvantages or barriers to the online learning environment included lack of clear expectations, scheduling, organization, and overall communication. Classroom participation, interaction with classmates, and group work during lecture times were seen as satisfying to some and dissatisfactory to others.

Published by Sciedu Press

\subsection{Learner characteristics}

The theme of learner characteristics included student motivation, time management and preferred learning style. Selfmotivated students appreciated asynchronous courses while others preferred enhanced guidance from instructors. Students who did not value a high degree of autonomy described a lack of motivation and focus leading to poor attention and attrition in relation to content which led to feelings of being overwhelmed.

In conclusion, the researchers identified four themes from the secondary analysis of data: learning environment, course design and delivery, communication, and learner characteristics, which appeared to be experienced by students along a continuum ranging from unfavorable to favorable. The combination of the student's experience of each of the four identified themes along the continuum appeared to collectively influence their perception of satisfaction and success within the online learning environment. This is additionally supported through the literature review as it was found the success of a student in the online environment is directly related to how the course content is delivered and the characteristics for autonomy the learner possesses. Refer to Figure 1 for a fictional example of how a student's collective experience of these themes might be expressed along this continuum, therefore affecting their experience within the online learning environment.

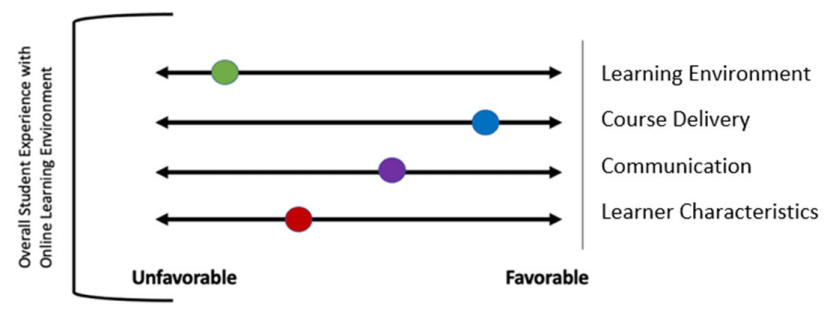

Figure 1. Fictional Example of Student Responses Along Response Continuum by Theme

\section{DisCUSSION}

Student perceptions of the advantages and disadvantages of online learning, satisfying and dissatisfying components, and barriers to learning were personal to, and differed between, individual students. The online learning environment is not a 'one size fits all' approach and should be tailored to the individual learner. This success depends partly on the individual learning style and motivation of the student. However, educators' methods of course delivery and utilization of communication can greatly impact the student's own personal learning experience within the online learning environment.

The findings from this study complement and extend the findings of the literature review. The review identified desired 
outcomes of online learning including motivation and attitude, self-efficacy, learning effectiveness, skill acquisition, and learner satisfaction. The findings of the current study identify four main themes reflecting different contributors to online learning as a series of continuum, from unfavorable to favorable. Utilizing all three authors for interpretation helped strengthen the themes emerging from the data. Shenton ${ }^{[25]}$ explains strategies to ensure trustworthiness in qualitative research projects based on Guba's four criteria of trustworthiness. In addition, Forero et al. ${ }^{[26]}$ describes four-dimension criteria to assess rigor in qualitative research. These two strategies were utilized to ensure validity and reliability in the secondary analysis. A student's position on each of the four continua appears to collectively influence how a student perceives the online learning environment. This perception can affect how satisfied the student will be in their online learning journey and how successful they will be in achieving the desired outcomes, identified in the review of literature, within an online learning environment.

\subsection{Implications for teaching}

It is vital for educators to understand and implement effective teaching modalities to enhance students' experiences in the online environment. Each student has different learning styles, and their learning experience should be tailored towards their individual needs. ${ }^{[27]}$ This includes, but is not limited to, appropriate and thorough content presentation and delivery for the online classroom, effective and clear communication to students regarding assignments and expectations, engaging content, and availability of faculty for communication with students who have questions and concerns. In a similar evaluation, Swan ${ }^{[27]}$ found students preferred organized courses with clear, consistent and concise learning outlines with distinct student expectations. Students found communication with faculty and classmates an important role in their learning outcomes for guidance and feedback. ${ }^{[27]}$ Educators do not have direct control over learner characteristics and the student's learning environment but can ensure students are aware of available resources to enhance their experience in a favorable direction in order to attain desired outcomes. Educators should provide a range of teaching and learning modalities to satisfy a variety of learners. The current interest in HyFlex modes of teaching, where content of a single course is available in a range of formats and delivery methods, seems promising in this respect. ${ }^{[28]}$ Since students' aggregate experience of their learning environment, course design and delivery, communication, and learner characteristics appears to be influential in students' overall satisfaction, faculty should consider each of these areas when planning online programs.

\subsection{Implications for future research}

Future research should include investigation into specific teaching modalities, examples of interventions, course design, course delivery, and methods of effective communication. There is a need for assessing learning styles and implementing specific teaching methods to tailor instruction to individual students. Research should investigate the online learning environment and determine appropriate training and resources needed to best prepare faculty, staff, and students throughout their courses and programs.

\subsection{Strengths and limitations}

Strengths of this study include its large sample and high response rate, thoughtful and rich responses from most of the participants, timely capture of experiences, and respondent anonymity, which is likely to result in more honest responses.

Limitations of the study include its homogenous sample, and cross-sectional methodology in which data were collected on only one sample, at one university, in a singular demographic location (Midwest region). The sample consisted of primarily young females of Caucasian origin with minimal representation of other demographic groups. This research was prompted by the changes in higher education delivery as a result of COVID-19. It is feasible for the student's response to have been influenced by the impact of the pandemic and the abrupt changes it caused to their education. This was a monumental change for educators across all fields, who had to quickly an entire course to fully online methodology. Given the rapid transition, better time to prepare for the online delivery could have enhanced course and delivery succession for educators and students alike. The research instrument was designed specifically for the purposes of the primary study and did not incorporate validated tools for the measurement of student satisfaction. However, for the purposes of this secondary analysis, we chose to focus on the subjective experiences of students, with findings suggesting that measurement of student satisfaction needs to be individually tailored to students' personal characteristics and learning styles.

\section{Conclusion}

In conclusion, attainment of desired learning outcomes within the online learning environment is influenced by learning environment, course design and delivery, communication, and learner characteristics. Individualization of the student's learning experience through tailored course delivery and support of learning needs will aid in increased satisfaction and achievement of learning outcomes.

\section{ACKNOWLEDGEMENTS}

The researchers would like to thank Dr. Sue Davies and Dr. 
Amy Koehler for guidance and continual support during the research process. Additionally, we are grateful to Dr. Diane Forsyth and Dr. Amy Smith for guidance and editorial

\section{REFERENCES}

[1] American Association of College of Nursing. (2020). Considerations for COVID-19 preparedness and response in U.S. schools of nursing. American Association of College of Nursing. Available from: https : //www . aacnnursing. org/Portals/42/AcademicNursing/p df/Considerations-for-COVID19-Nursing-Schools.pdf

[2] Sinacori BC. How nurse educators perceive the transition from the traditional classroom to the online environment: A qualitative inquiry. Nursing Education Perspectives (Wolters Kluwer Health). 2020; 41(1): 16-19. PMid:31860479 https://doi.org/10.1097/01. N EP. 0000000000000490

[3] Thai NTT, De Wever B, Valcke M. Face-to-face, blended, flipped, or online learning environment? Impact on learning performance and student cognitions. Journal of Computer Assisted Learning. 2020; 36(3): 397-411. https://doi.org/10.1111/jcal.12423

[4] Billings DM, Halstead JA. Teaching in nursing: A guide for faculty (6th ed.). St Louis, MO: Elsevier Saunders. 2019.

[5] Esposito CP, Sullivan K. Maintaining clinical continuity through virtual simulation during the COVID-19 pandemic. Journal of Nursing Education. 2020; 59(9): 522-525. PMid:32865587 https: //doi.org/10.3928/01484834-20200817-09

[6] United States Department of Education. Evaluation of evidencebased practices in online learning: A meta-analysis and review of online learning studies. Washington, DC: U.S. Department of Education, Office of Planning, Evaluation and Policy Development, Policy and Program Studies Service. 2010. Available from: https://www2.ed.gov/rschstat/eval/tech/evidenc e-based-practices/finalreport.pdf

[7] Gagnon MP, Gagnon J, Desmartis M, et al. The impact of blended teaching on knowledge, satisfaction, and self-directed learning in nursing undergraduates: A randomized, controlled trial. Nursing Education Perspectives (National League for Nursing). 2013; 34(6): 377-382. PMid:24475598 https://doi .org/10.5480/10-459

[8] McCutcheon K, O'Halloran P, Lohan M. Online learning versus blended learning of clinical supervisee skills with pre-registration nursing students: A randomized controlled trial. International Journal of Nursing Studies. 2018; 82: 30-39. PMid:29574394 https: //doi.org/10.1016/j.ijnurstu.2018.02.005

[9] Li C, He J, Yuan C, et al. The effects of blended learning on knowledge, skills, and satisfaction in nursing students: A metaanalysis. Nurse Education Today. 2019; 82: 51-57. PMid:31437783 https://doi.org/10.1016/j.nedt.2019.08.004

[10] Bastable SB. Nurse as educator: Principles of teaching and learning for nursing practice. 5th ed. Burlington, MA: Jones \& Bartlett Learning. 2020

[11] Cant RP, Cooper SJ. Use of simulation-based learning in undergraduate nurse education: An umbrella systematic review. Nurse Education Today. 2017; 49: 63-71. PMid:27902949 https://doi .org/10.1 016/j.nedt.2016.11.015

[12] Shorey S, Kowitlawakul Y, Devi M, et al. Blended learning pedagogy designed for communication module among undergraduate nursing students: A quasi-experimental study. support.

\section{Conflicts of InTEREST Disclosure}

The authors declare that there is no conflict of interest.
Nurse Education Today. 2018; 61: 120-126. PMid:29197264 https://doi.org/10.1016/j.nedt.2017.11.011

[13] Chan AW, Chair SY, Sit JW, et al. Case-based web learning versus face-to-face learning: A mixed-method study on university nursing students. The Journal of Nursing Research. 2016; 24(1): 31-40. PMid:26258389 https://doi.org/10.1097/jnr.0000000000 000104

[14] Giddens JF, Shuster G, Roehrig N. Early student outcomes associated with a virtual community for learning. Journal of Nursing Education. 2010; 49(6): 355-358. PMid:20210288 https://doi.org/10.3 928/01484834-20100217-03

[15] Gill M, Andersen E, Hilsmann N. Best practices for teaching pharmacology to undergraduate nursing students: A systematic review of the literature. Nurse Education Today. 2019; 74: 15-24. PMid:30554030 https://doi.org/10.1016/j.nedt.2018.11.017

[16] McCutcheon K, Lohan M, Traynor M, et al. A systematic review evaluating the impact of online or blended learning vs face-to-face learning of clinical skills in undergraduate nurse education. Journal of Advanced Nursing. 2015; 71(2): 255-270. PMid:25134985 https://doi.org/10.1111/jan.12509

[17] Blissitt AM. Blended learning versus traditional lecture in introductory nursing pathophysiology courses. Journal of Nursing Education. 2016; 55(4): 227-230. PMid:27023894 https://doi.org/10.3 928/01484834-20160316-09

[18] Graber J. Comparison of mental health nursing student academic achievement and satisfaction: Classroom versus online education in teaching therapeutic crisis management techniques. Issues in Mental Health Nursing. 2019; 40(3): 247-251. PMid:30412433 https://doi.org/10.1080/01612840.2018.1505985

[19] William A, Vidal VL, John P. Traditional instruction versus virtual reality simulation: A comparative study of phlebotomy training among nursing students in kuwait. Journal of Education and Practice. 2016; 7(9): 18-25.

[20] Scarbrough JE. Synchronous videoconferencing in distance education for pre-licensure nursing. Journal of Education and Training Studies. 2015; 3(4): 68-72. https://doi.org/10.11114/jets. v3i4. 797

[21] Yeh VJ, Sherwood G, Durham CF, et al. Designing and implementing asynchronous online deliberate practice to develop interprofessional communication competency. Nurse Education in Practice. 2019; 35: 21-26. PMid:30640047 https://doi.org/10.1016/j.nepr.2 018.12 .011

[22] Munich K. Social support for online learning: Perspectives of nursing students. International Journal of E-Learning \& Distance Education. 2014; 29(2): 1-12.

[23] Ritchie J, Spencer L. Qualitative data analysis for applied policy research. In A. 1994. Bryman \& R. Burgess (Eds.), Analyzing qualitative data (pp.172-194). Routledge.

[24] Ward DJ, Furber C, Tierney S, et al. Using framework analysis in nursing research: a worked example. Journal of Advanced Nursing 2013; 69(11): 2423-2431. PMid:23517523 https ://doi .org/10 $.1111 / j$ an. 12127 
[25] Shenton A. Strategies for ensuring trustworthiness in qualitative research projects. Education for Information. 2004; (22): 63-75. https://doi .org/10.3233/EFI-2004-22201

[26] Forero R, Nahidi S, De Costa J, et al. Application of four-dimension criteria to assess rigor of qualitative research in emergency medicine. BMC Health Services Research. 2018; 18(1). PMid:29454350 https://doi.org/10.1186/s12913-018-2915-2
[27] Swan K. Learning effectiveness online: What the research tell us. Elements of Quality Online Education, Practice and Direction. 2003; 13-45.

[28] Dorsey L, Kettenbach G, Beckel C, et al. Implementation of hyflex professional physical therapy education within the COVID-19 blindspot. Journal of Allied Health. 2021; 50(1): 87-88. 